\title{
Overweight and obesity repercussion in the postoperative of myocardial revascularization surgery
}

\author{
REPERCUSSÃO DO SOBREPESO E DA OBESIDADE NO PÓS-OPERATÓRIO DA \\ CIRURGIA DE REVASCULARIZAÇÃO MIOCÁRDICA
}

\author{
REPERCUSIÓN DEL SOBREPESO Y DE LA OBESIDAD EN EL POSTOPERATORIO DE \\ LA CIRUGÍA DE REVASCULARIZACIÓN MIOCÁRDICA
}

\author{
Nyagra Ribeiro de Araujo1, Raul Amaral de Araújo², Simone Maria Muniz da Silva Bezerra³
}

\begin{abstract}
This is a descriptive, retrospective study with cross-sectional quantitative approach, which aimed to relate the body mass index with events in the postoperative period of the myocardial revascularization surgery with use of extracorporeal circulation. The data collection period was between April and June/2012. Patients were divided according to the body mass index and classified as without excess of weight, overweight or obese. The data analysis was based on the descriptive statistics. The patients without excess of weight had more complications, especially those related to the lungs. Among overweight and obese individuals, the cardiovascular complications stood out. The obese subjects had the worse prognostic. Obesity and overweight did not have statistically significant association with a higher frequency of postoperative complications, in spite of the occurrence of cardiovascular complications in this group. The patients without excess of weight had higher risks of developing neurological events.
\end{abstract}

\section{RESUMO}

Estudo descritivo, transversal e retrospectivo, com abordagem quantitativa, cujo objetivo foi relacionar o índice de massa corporal (IMC) a eventos do pós-operatório da cirurgia de revascularização miocárdica. A coleta de dados ocorreu entre abril e junho de 2012. Os participantes foram divididos de acordo com o índice de massa corporal em três grupos: não obesos, com sobrepeso e obesos. A análise de dados baseou-se na estatística descritiva. Verificou-se que os participantes não obesos tiveram mais complicações, notadamente as pulmonares. Dentre os indivíduos com sobrepeso e obesidade sobressaíram-se as complicações cardiovasculares. Os obesos tiveram pior prognóstico. Concluiu-se que a obesidade e o sobrepeso não tiveram associação estatisticamente significativa com maior frequência de complicações pós-operatórias, apesar da ocorrência de complicações cardiovasculares nesses grupos. O conhecimento dessas possíveis complicações possibilita o planejamento adequado da assistência de enfermagem, a partir da prática baseada em evidências.

\section{DESCRITORES \\ Obesidade \\ Índice de massa corporal \\ Revascularização miocárdica \\ Complicações pós-operatórias \\ Enfermagem perioperatória}

\section{RESUMEN}

Estudio descriptivo, transversal y retrospectivo de abordaje cuantitativo, cuyo objetivo fue relacionar el Índice de Masa Corporal (IMC) a los eventos ocurridos en el postoperatorio de la cirugía de revascularización miocárdica. La recolección de datos se realizó entre abril y junio del 2012. Los participantes fueron divididos según su IMC en tres grupos: aquellos con estado nutricional normal, con sobrepeso y obesos. El análisis de datos se basó en la estadística descriptiva. Se encontró que los participantes eutróficos tuvieron más complicaciones, especialmente pulmonares. Ente los individuos con sobrepeso y obesidad destacaron las complicaciones cardiovasculares, teniendo los sujetos con obesidad peor pronóstico. Se concluyó que no existe asociación estadísticamente significativa entre la obesidad y el sobrepeso con la mayor frecuencia de complicaciones postoperatorias a pesar de la ocurrencia de complicaciones cardiovasculares en esos grupos. El conocimiento de esas posibles complicaciones posibilita la planificación adecuada de los cuidados de enfermería a partir de la práctica basada en la evidencia.

\author{
DESCRIPTORES \\ Obesidad \\ Índice de masa de corporal \\ Revascularización miocárdica \\ Complicaciones postoperatorias \\ Enfermería perioperatoria
}

${ }^{1}$ Master student of the Post-graduation Associate Program in Nursing, Universidade de Pernambuco, Universidade Estadual da Paraíba, Recife, PE, Brazil. ${ }^{2}$ Master student of the Post-graduation Program in Nursing, Universidade Federal de Pernambuco, Recife, PE, Brazil. ${ }^{3}$ Professor, Faculdade de Enfermagem Nossa Senhora das Graças, Universidade de Pernambuco, Recife, PE, Brazil. simonemunizm2@gmail.com 


\section{INTRODUCTION}

In the last few decades people are consuming more high energy density foods with high levels of sugar and saturated fats. These nutritional habits combined with increased physical inactivity are expanding very rapidly in developing countries ${ }^{(1)}$.

In Brazil, the analysis of secular trends indicates that obesity among adults is expanding, reaching at least $10 \%$ of the population in all regions of the country between 2008 and $2009^{(2)}$. Projections based on national surveys conducted in recent decades estimate that in 2015 obesity will reach $40 \%$ of the U.S. population, $30 \%$ of the English and $20 \%$ of the Brazilian ${ }^{(3)}$.

Obesity generates a significant state of personal and collective suffering, given the impact of its numerous comorbidities, including metabolic disorders such as metabolic syndrome and diabetes, gallbladder diseases, hypertension, orthopedic problems, cardiovascular disease (CVD), cancer and sleep apnea(4).

The nutritional status affects how individuals tolerate the fact of undergoing heart surgery. The clinical condition of patients, length of hospital stay and treatment response are directly influenced by obesity, which is associated with elevated morbidity, mortality and hospital costs ${ }^{(5-6)}$.

Coronary heart diseases (CHD) particularly stand out because of their association with overweight and obesity in affected individuals. In many patients, the impairment becomes so extensive that drug or percutaneous therapies are insufficient to maintain a good quality of life. Therefore, more invasive procedures such as coronary artery bypass grafting (CABG) are required ${ }^{(7)}$.

In the literature are observed contradictions regarding the influence of body mass index (BMI) in the CABG postoperative phase. In some studies, a high BMI - indicating overweight or obesity - was not associated with postoperative complications, while other studies have shown a positive association between overweight, obesity and CABG postoperative complications ${ }^{(8-11)}$.

There is a lack of knowledge about the influence of overweight and obesity in postoperative adversities in cardiac surgery, which requires studies addressing this issue. Thus, the development of this study is justified, aiming at relating the body mass index with events of the CABG postoperative period.

\section{METHOD}

This is a descriptive and retrospective study with crosssectional quantitative approach ${ }^{(11)}$ carried out by analysis of medical records of patients undergoing CABG in a 12 month period (March/2011 to February/2012) at the
Professor Luiz Tavares Cardiology Emergency Hospital of Pernambuco located in the Universidade de Pernambuco (PROCAPE/UPE). This is a reference institution in cardiology for the North and Northeast regions of Brazil.

The study included patients of both sexes who underwent CABG with median sternotomy and cardiopulmonary bypass (CPB). Were excluded those with valvular disease who underwent valvuloplasty or valve replacement, those who underwent CABG without CPB, those who had previously undergone $C A B G$ and individuals whose medical records had missing or insufficient information. The application of inclusion and exclusion criteria resulted in a sample of 124 individuals.

The data collection period was between April and June 2012. Information from admission until discharge was extracted from medical records of individuals, comprising the following independent variables: data from case histories and physical examinations, comorbidities and life habits present in the preoperative phase, clinical presentation of coronary artery disease (CAD) on admission, data of the intraoperative phase, postoperative complications and length of stay.

The outcome variable was the $\mathrm{BMI}$, according to the World Health Organization (WHO) $)^{(12)}$ cutoffs, namely: no excess of weight for $\mathrm{BMI}<25 \mathrm{~kg} / \mathrm{m}^{2}$, overweight for BMI $\geq 30 \mathrm{~kg} / \mathrm{m}^{2}$ and obesity for $\mathrm{BMI} \geq 30 \mathrm{~kg} / \mathrm{m}^{2}$. Hence, three $\mathrm{BMI}$ groups were analyzed in this study.

The variables were tabulated and analyzed using descriptive statistics with the STATA/SE 9.0 software. The Kolmogorov-Smirnov test was used to determine the use of parametric and nonparametric tests. The chi-squared test and the Fisher's exact test were used for categorical variables ${ }^{(13)}$. The groups were compared by analysis of variance (ANOVA), when the Kolmogorov-Smirnov test showed normal distribution. In opposite cases, the Kruskal-Wallis test was applied. All tests were applied with a $95 \%$ confidence interval and only values of $p<0.05$ were expressed in the tables ${ }^{(13)}$.

The study was approved by the Ethics Committee in Research of the Complexo Hospitalar Hospital Universitário Oswaldo Cruz/Pronto-Socorro Cardiológico de Pernambuco (HUOC/PROCAPE) and by the CAAE number 0169.0.106.000-11.

\section{RESULTS}

Firstly, individuals were classified according to BMI groups. A total of 39 people (31.4\%) did not have excess of weight, 60 (48.4\%) were overweight and 25 (20.2\%) were obese. In the study sample the male gender was predominant $(n=76 ; 61.3 \%)$, as well as the categories 'no excess of weight' and 'overweight'. The female gender was predominant in the obesity group. The mean age was lower in the obese group (60.76 \pm 10.87 years), as shown in Table 1 .
Overweight and obesity repercussion in the postoperative of myocardial revascularization surgery Araujo NR, Araújo RA, Bezerra SMMS 
Regarding the manifestation of CHD at hospital admission, in all three groups it was observed an increased prevalence of non-ST-elevation myocardial infarction (NSTEMI). However, all forms of manifestation had similar distribution frequencies. The systemic arterial hypertension (SAH) and diabetes mellitus (DM) were more prevalent among the obese. Smoking, dyslipidemia, alcoholism and chronic ob- structive pulmonary disease (COPD) were more frequent among overweight patients. The incidence of renal insufficiency (RI) stood out in subjects without excess of weight. The history of smoking was common in all three categories. A higher frequency of previous acute myocardial infarction (AMI) and percutaneous transluminal coronary angioplasty (PTCA) was observed among obese individuals.

Table 1 - Characteristics of patients who underwent CABG between March/2011 and February/2012 - Recife, PE

\begin{tabular}{|c|c|c|c|c|}
\hline \multirow[b]{2}{*}{ Variables } & \multicolumn{3}{|c|}{ BMI } & \multirow[b]{2}{*}{ p-value } \\
\hline & $<25$ & $25 \mid-30$ & $\geq \mathbf{3 0}$ & \\
\hline Male gender, n (\%) & $30(76.9)$ & $39(65.0)$ & $07(28.0)$ & \multirow{2}{*}{$<0.001^{*}$} \\
\hline Age, mean $( \pm \mathrm{SD})$ & $62.82( \pm 8.04)$ & $62.10( \pm 8.79)$ & $60.76( \pm 10.87)$ & \\
\hline \multicolumn{5}{|l|}{ Manifestation of CAD } \\
\hline SA, n (\%) & $07(17.9)$ & $16(26.6)$ & $06(24.0)$ & \\
\hline UA, $n(\%)$ & $12(30.8)$ & $12(20.0)$ & $06(24.0)$ & \\
\hline Asymptomatic, n (\%) & $00(0.0)$ & $01(1.7)$ & $00(0.0)$ & \\
\hline STEMI, n (\%) & $05(12.8)$ & $07(11.7)$ & $02(8.0)$ & \\
\hline NSTEMI, n (\%) & $15(38.5)$ & $24(40.0)$ & $11(44.0)$ & \\
\hline \multicolumn{5}{|l|}{ Comorbidities } \\
\hline $\mathrm{SAH}, \mathrm{n}(\%)$ & $33(86.8)$ & $57(95.0)$ & $24(96.0)$ & \\
\hline Smoking, n (\%) & $18(46.2)$ & $33(55.0)$ & $12(48.0)$ & \\
\hline Dyslipidemia, n (\%) & $20(51.3)$ & $40(66.7)$ & $11(44.0)$ & \\
\hline DM, n $(\%)$ & $17(43.6)$ & $25(41.7)$ & $15(60.0)$ & \\
\hline RI, n (\%) & $08(20.5)$ & $02(3.3)$ & $00(0.0)$ & $0.004 * *$ \\
\hline CVA, n $(\%)$ & $05(12.8)$ & $05(8.3)$ & $03(12.0)$ & \\
\hline COPD, n (\%) & $03(7.7)$ & $06(10.0)$ & $00(0.0)$ & \\
\hline Previous AMI, n (\%) & $11(28.2)$ & $25(41.7)$ & $11(44.0)$ & \\
\hline Previous PTCA, n (\%) & $06(15.4)$ & $09(15.0)$ & $06(24.0)$ & \\
\hline
\end{tabular}

SD - Standard deviation; CAD - coronary artery disease; SA - stable angina; UA - unstable angina; STEMI - ST-elevation myocardial infarction; NSTEMI - non-ST-elevation myocardial infarction; SAH - systemic arterial hypertension; DM - diabetes mellitus; RI - renal insufficiency; CVA - cerebrovascular accident; COPD - chronic obstructive pulmonary disease; AMI - acute myocardial infarction; PTCA - percutaneous transluminal coronary angioplasty.

${ }^{*}$ Chi-squared test. ${ }^{* *}$ Fisher's exact test.

The mean duration of surgery and of the cardiopulmonary bypass (CPB) was higher among overweight individuals: 273.41 ( \pm 65.09) minutes and 97.89 ( \pm 32.97) minutes, respectively. Among the obese, the average time of surgery was $262.69( \pm 58.55)$ minutes and the mean CPB time was 94.29 ( \pm 38.42) minutes. Obese patients were those who required higher number of grafts, with an average of 2.72 ( \pm 0.74$)$, as shown in Table 2 .
Patients without excess of weight spent more time hospitalized for the surgery, an average of 16.90 ( \pm 11.17) days, while the obese remained hospitalized for $13.76( \pm 8.94)$ days. On average, the total length of stay was $33.05( \pm 21.80)$ and $24.48( \pm 9.17)$ days, and the postoperative hospital stay was $16.15( \pm 16,39)$ and $10.72( \pm 6.25)$ days for patients without excess of weight and obese, respectively.

Table 2 - Perioperative variables of patients who underwent CABG between March/2011 and February/2012 - Recife-PE*

\begin{tabular}{|c|c|c|c|}
\hline \multirow{3}{*}{ Variables } & \multicolumn{3}{|c|}{ BMI } \\
\hline & $<25$ & $25 \mid-30$ & $\geq \mathbf{3 0}$ \\
\hline & Mean $( \pm$ SD) & Mean ( \pm SD) & Mean $( \pm$ SD) \\
\hline Age & $62.82( \pm 8.04)$ & $62.10( \pm 8.79)$ & $60.76( \pm 10.87)$ \\
\hline Number of grafts & $2.49( \pm 0.79)$ & $2.67( \pm 0.80)$ & $2.72( \pm 0.74)$ \\
\hline Surgery time & $255.26( \pm 78.99)$ & $273.41( \pm 65.09)$ & $262.69( \pm 58.55)$ \\
\hline CPB time & $87.89( \pm 31.55)$ & $97.89( \pm 32.97)$ & $94.29( \pm 38.42)$ \\
\hline Time of pre-surgical hospitalization & $16.90( \pm 11.17)$ & $15.83( \pm 12.08)$ & $13.76( \pm 8.94)$ \\
\hline Time of post-surgical hospitalization & $16.15( \pm 16.39)$ & $13.13( \pm 11.51)$ & $10.72( \pm 6.25)$ \\
\hline Total hospitalization time & $33.05( \pm 21.80)$ & $29.00( \pm 17.52)$ & $24.48( \pm 9.17)$ \\
\hline
\end{tabular}

CPB - cardiopulmonary bypass. *ANOVA and Kruskal-Wallis tests were applied, but there was no statistically significant p value. 
The relative frequency of postoperative complications among individuals without excess of weight was $53.8 \%$, in obese it was $48 \%$ and $41.7 \%$ in overweight individuals. The most common complications among those without excess of weight were pulmonary, whereas in overweight patients cardiovascular predominated, and in obese, cardiovascular and lung complications predominated in equal numbers (Table 3 ).

Table 3 - Major postoperative complications in patients who underwent CABG between March/2011 and February/2012 - Recife, PE

\begin{tabular}{|c|c|c|c|c|}
\hline \multirow{3}{*}{ Variables } & \multicolumn{3}{|c|}{ BMI } & \multirow{3}{*}{ p-value } \\
\hline & $<25$ & $25 \mid-30$ & $\geq \mathbf{3 0}$ & \\
\hline & $\mathbf{N}(\%)$ & N (\%) & N (\%) & \\
\hline Total complications by category & $21(53.8)$ & $25(41.7)$ & $12(48.0)$ & \\
\hline Cardiovascular & $8(20.5)$ & $17(28.3)$ & $6(24.0)$ & \multirow{24}{*}{$0.044 * *$} \\
\hline $\mathrm{AF}$ & $4(10.3)$ & $6(10.0)$ & $2(8.0)$ & \\
\hline LV Dysfunction & $1(2.6)$ & $7(11.7)$ & $1(4.0)$ & \\
\hline LCOS & $2(5.1)$ & $6(10.0)$ & $3(12.0)$ & \\
\hline $\mathrm{CPA}$ & $3(7.7)$ & $4(6.7)$ & $3(12.0)$ & \\
\hline Respiratory & $12(30.8)$ & $10(16.7)$ & $6(24.0)$ & \\
\hline Respiratory failure & $3(7.7)$ & $2(3.3)$ & $1(4.0)$ & \\
\hline Respiratory infection & $7(17.9)$ & $7(11.7)$ & $4(16.0)$ & \\
\hline Pleural effusion & $7(17.9)$ & $5(8.3)$ & $1(4.0)$ & \\
\hline Renal & $7(17.9)$ & $4(6.7)$ & $1(4.0)$ & \\
\hline Renal insufficiency & $6(15.4)$ & $2(3.3)$ & $1(4.0)$ & \\
\hline Urinary infection & $4(10.3)$ & $2(3.3)$ & $0(0.0)$ & \\
\hline Neurological & $5(12.8)$ & $4(6.7)$ & $3(12.0)$ & \\
\hline CVA & $5(12.8)$ & $1(1.7)$ & $1(4.0)$ & \\
\hline TIA & $0(0.0)$ & $1(1.7)$ & $1(4.0)$ & \\
\hline Convulsion & $0(0.0)$ & $2(3.3)$ & $2(8.0)$ & \\
\hline Others & $9(23.1)$ & $9(15.0)$ & $3(12.0)$ & \\
\hline Bleeding & $0(0.0)$ & $2(3.3)$ & $0(0.0)$ & \\
\hline Infection of thoracic SW & $3(7.7)$ & $1(1.7)$ & $1(4.0)$ & \\
\hline Infection of saphenectomy & $5(12.8)$ & $5(8.3)$ & $1(4.0)$ & \\
\hline Mediastinitis & $1(2.6)$ & $0(0.0)$ & $1(4.0)$ & \\
\hline Sepsis & $2(5.1)$ & $1(1.7)$ & $1(4.0)$ & \\
\hline Reoperation & $0(0.0)$ & $4(6.7)$ & $0(0.0)$ & \\
\hline Death & $5(12.8)$ & $4(6.7)$ & $4(16.0)$ & \\
\hline
\end{tabular}

AF - atrial fibrilation; LV - left ventricle; LCOS - low cardiac output syndrome; CPA - cardiopulmonary arrest; CVA - cerebrovascular accident; TIA - transient ischemic attack; SW - surgical wound. **Fisher's exact test.

In participants without excess of weight, the most common complications were respiratory infection (17.9\%), pleural effusion $(17.9 \%)$, renal failure $(15.4 \%)$, stroke $(12.8 \%)$, infection of saphenectomy $(12.8 \%)$ and death (12.8\%). In overweight individuals the following occurred: left ventricular dysfunction $(11.7 \%)$, respiratory infection (11.7\%), atrial fibrillation (10\%) and low cardiac output syndrome (10\%). In obese individuals were observed respiratory infection $(16 \%)$, LCOS $(10 \%)$, cardiopulmonary arrest $(10 \%)$ and death (16\%).

\section{DISCUSSION}

It was significantly found $(p<0,001)$ that even though women underwent CABG less, they were obese when doing it, predicting a worse prognosis ${ }^{(14-15)}$. However, in another study ${ }^{(16)}$, the number of men was more prevalent, even in the group of obese patients.

The prevalent form of manifestation of CAD in hospital admission, regardless of BMI, was the NSTEMI, a more serious medical condition than that found in a study comparing subjects with $\mathrm{BMI}<30$ and $\geq 30 \mathrm{~kg} / \mathrm{m}^{2}$, and finding a higher prevalence of UA in patients admitted to hospital ${ }^{(17)}$.

The RI was the only statistically significant comorbidity $(p=0.004)$, for its prevalence among patients without excess of weight, in agreement with other reviewed studies, in which individuals with lower BMI had a higher frequency of $\mathrm{RI}^{(9,16)}$, probably because of protein-calorie malnutrition resulting from dietary restrictions, hormonal disturbances and loss of nutrients during dialysis ${ }^{(18)}$. 
A higher occurrence of CVA was identified in patients with $\mathrm{BMI}<25 \mathrm{~kg} / \mathrm{m}^{2}$ in the postoperative CABG period. However, a similar study found a higher prevalence of CVA in obese people ${ }^{(9)}$, while another study showed that the prevalence of CVA in the CABG postoperative period was similar among obese and non-obese subjects $^{(10)}$. In the preoperative period, the category of $\mathrm{BMI}<25 \mathrm{~kg} / \mathrm{m}^{2}$ was also associated with greater positive history for CVA.

In the postoperative period of cardiac surgery, neurologic complications are multifactorial, including pre, intra and postoperative risk factors such as age, gender, previous neurological disease, carotid artery disease, microembolisms, perfusion disorders, metabolic disorders and inflammatory responses ${ }^{(10)}$.

In this study, the CPB time was lower among patients without excess of weight and higher in overweight patients. In general, it is known that the time of surgery is directly related to CPB time ${ }^{(19)}$. In some studies ${ }^{(17,20)}$ in which there was statistically significant difference, the CPB time was lower in patients without excess of weight and overweight and higher in obese patients.

Individuals without excess of weight had higher total hospitalization time, but in another study, the obese had longer hospital stays ${ }^{(16)}$. The overweight and obese individuals were probably treated more aggressively with more precocious surgical procedure, while patients with a $\mathrm{BMI}<25 \mathrm{~kg} / \mathrm{m} 2$ had longer postoperative hospital stay and presented major complications.

The higher prevalence of cardiovascular complications in the categories of overweight and obesity was because obesity is an indirect cause of heart diseases, and related to hemodynamic changes (high blood pressure, elevated heart rate), metabolic (dyslipidemia) and ventricular hypertrophy, with consequent progressive atrial dilatation. All this can contribute to the occurrence of $\mathrm{AF}$ and $\mathrm{LCOS}^{(21)}$.

A study that classified its sample in non-obese and obese found that obese individuals had higher number of deaths, mediastinitis, CVA, respiratory failure and infection, sepsis and $A F$ and the non-obese had more myocardial infarction and CPA ${ }^{(16)}$. In another study, obese patients had more respiratory failure, surgical wound infection (chest and saphenous), sepsis, heart attack and kidney insufficiency. The non-obese had more AF, CPA, bleeding and reoperation ${ }^{(17)}$.

In the present study, the higher morbidity and mortality among obese patients may be related to the fact that this group was composed predominantly of females. The literature reveals higher rates of morbidity and mortality in women than in men undergoing $\mathrm{CABG}^{(22)}$.

The results of this study also showed that the group with $\mathrm{BMI}<25 \mathrm{~kg} / \mathrm{m} 2$ was comprised of seniors with the highest average age among the BMI categories and a greater number of postoperative complications.
Although the findings do not have statistical significance, malnutrition in the elderly is known to be related to adverse surgical outcomes as it affects the immune competence and the ability to manage stress. This was evidenced by a study in which the nutritional impairment was related to longer hospital stays and rehabilitation, increased risk of infection and poor healing of surgical wounds ${ }^{(23)}$.

Another study ${ }^{(9)}$ showed that a $\mathrm{BMl}<22 \mathrm{~kg} / \mathrm{m}^{2}$ may increase the incidence of postoperative complications in elderly patients undergoing CABG and that obesity (considered with a $\mathrm{BMI}>27 \mathrm{~kg} / \mathrm{m}^{2}$ ), in contrast, may have a protective effect, except for cases of renal dysfunction. The term 'obesity paradox' has been used to express this protective relation that increasing weight seems to exert on the various cardiovascular events. In myocardial revascularization, either percutaneous or surgical, the extremes of a nutritional status, ie, low weight and severe obesity, have been linked to unfavorable outcomes when compared to overweight or obese patients ${ }^{(24-25)}$.

\section{CONCLUSION}

Although it has not been observed a statistically significant association between overweight and obesity and a higher frequency of complications after CABG in this study, we found that obese patients were younger and predominantly female, had more grafts in the CABG procedure and showed higher mortality. Overweight individuals had longer time of surgery, CPB and a higher prevalence of cardiovascular complications.

Regarding those individuals with BMI $<25 \mathrm{~kg} / \mathrm{m} 2$, it was found that they had worse renal function, higher mean age, greater frequency of complications and prolonged hospital stay. Furthermore, these patients had a higher risk of developing neurological events.

The limitations of this study are mainly due to its descriptive and retrospective aspects, which limit the provision of models for prediction. Nevertheless, the results help to indicate which comorbidities deserve attention in future research and in the evaluation of surgical risks related to BMI.

This study is particularly relevant for the nursing field because the knowledge of possible complications that occur in a particular subgroup of patients in the postoperative period of cardiac surgery allows the appropriate care planning, from evidence-based practices.

In this sense is revealed the interaction and mutual supply between research and practice in nursing through the incorporation of knowledge produced by research in everyday practice, as well as the recognition of the need for experimental studies to evaluate the relations of cause and effect between BMI and events in the CABG postoperative period. 


\section{REFERENCES}

1. Chaves VLV, Freese E, Lapa TM, Cesse EAP, Vasconcelos ALR. Evolução espaço-temporal do sobrepeso e da obesidade em adolescentes masculinos Brasileiros, 1980 a 2005. Cad Saúde Pública. 2010;26(7):1303-13.

2. Instituto Brasileiro de Geografia e Estatística (IBGE). Pesquisa de Orçamentos Familiares 2008-2009. Antropometria e estado nutricional de crianças, adolescentes e adultos no Brasil. [Internet]. Rio de Janeiro; 2010 [citado 2012 set. 29]. Disponível em: http://www.ibge.com.br/home/estatistica/populacao/condicaodevida/pof/2008_2009_encaa/default.shtm

3. Hu F. Measurements of adiposity and body composition. In: Hu F, editor. Obesity epidemiology. New York: Oxford University Press; 2008. p. 53-83.

4. Rossetti MB, Britto RR, Norton RC. Prevenção primária de doenças cardiovasculares na obesidade infantojuvenil: efeito anti-inflamatório do exercício físico. Rev Bras Med Esporte. 2009;15(6):472-5.

5. Crestani1 N, Bieger P, Kik RME, Dias RL, Alscher S, Lienert RSC. Perfil nutricional de pacientes adultos e idosos admitidos em um hospital universitário. Ciênc Saúde. 2011;4(2):45-9.

6. Magalhães MGPA, Alves LMO, Alcântara LFM, Bezerra SMMS. Post-operative mediastinitis in a heart hospital of Recife: contributions for nursing care. Rev Esc Enferm USP [Internet]. 2012 [cited 2013 Aug 10];46(4):865-71. Available from: http://www.scielo.br/pdf/reeusp/v46n4/en_12.pdf.

7. Gomes F, Telo DF, Souza HP, Nicolau JC, Halpern A, Serrano Junior CV. Obesidade e doença arterial coronariana: papel da inflamação vascular. Arq Bras Cardiol. 2010;94(2):273-9.

8. King-Shier KM, Leblanc $P$, Mather C, Sandham S, Seneviratne C, Maitland A. Weight and Patients' decision to undergo cardiac surgery. Clin Nurs Res. 2013;22(2):228-49.

9. Reis C, Barbiero SM, Ribas L. O efeito do índice de massa corporal sobre as complicações no pós-operatório de cirurgia de revascularização do miocárdio em idosos. Rev Bras Cir Cardiovasc. 2008;23(4):524-9.

10. Nina VJS, Rocha MIA, Rodrigues RF, Oliveira VC, Teixeira JLL, Figueredo ED, et al. Avaliação do escore CABDEAL como preditor de disfunção neurológica no pós-operatório de revascularização miocárdica com circulação extracorpórea. Rev Bras Cir Cardiovasc. 2012;27(3):429-35.

11. Polit DF, Beck CT. Fundamentos de pesquisa em enfermagem: avaliação de evidências para a prática da enfermagem. 7a ed. Porto Alegre: Artmed; 2011.

12. World Health Organization (WHO). Child Growth Standards. Physical status: the use and interpretation of anthropometry. Report of a WHO Expert Committee. Geneva; 2013.

13. Agresti A, Finlay B. Métodos estatísticos para as ciências sociais. 4a ed. Porto Alegre: Penso; 2012.
14. Godoy PH, Oliveira GMM, Silva NAS, Klein CH. Diferença nas taxas de letalidade e nas principais causas de óbito, entre homens e mulheres, por revascularização miocárdica cirúrgica. Rev SOCERJ. 2008;21(3):148-53.

15. Santos FCP, Gazzi LAP, Libardi MC, Santos DFP, Silva DVB, Fichinno MZS, et al. Epidemiologia e manejo dos fatores de risco na síndrome coronariana aguda na mulher. Rev Fac Ciênc Méd Sorocaba. 2009;11(2):6-11.

16. Guaragna LP, Dall'Alba DP, Goulart PR, Guaragna JCVC, Bodanese LC, Magedanz EH, et al. O impacto da obesidade na morbi-mortalidade de pacientes submetidos à cirurgia de revascularização miocárdica. Sci Med. 2008;18(2):75-80.

17. Alan M, Siddiqui S, Lee V, Elayda MA, Nambi V, Yang EY, et al. Isolated coronary artery bypass grafting in obese individuals. Circ J. 2011;75(6):1378-85.

18. Oliveira $C M C$, Kubrusly $M$, Mota $R S$, Silva $C A B$, Oliveira VN. Desnutrição na insuficiência renal crônica: qual o melhor método diagnóstico na prática clínica? J Bras Nefrol. 2010;32(1):57-70.

19. Kaya K, Cavolli R, Telli A, Soyal MF, Aslan A, Gokaslan G, et al. Off-pump versus on-pump coronary artery bypass grafting in acute coronary syndrome: a clinical analysis. J Cardiothorac Surg [Internet]. 2010 [cited 2012 Sept 29];5(31):[about 8p]. Available from: http://www.ncbi.nlm.nih.gov/pmc/articles/PMC2873363/pdf/1749-8090-5-31.pdf

20. Le-Berta G, Santana O, Pineda AM, Zamora C, Lamasa GA, Lamelas J. The obesity paradox in elderly obese patients undergoing coronary artery bypass surgery. Interact Cardiovasc Thorac Surg. 2011;13(2):124-7.

21. Wanahita N, Messerli FH, Bangalore S, Gami AS, Somers VK, Steinberg JS, et al. Atrial fibrillation and obesity: results of a meta-analysis. Am Heart J. 2008;155(2):310-5.

22. Oliveira EL, Westphal GA, Mastroeni MF. Características clínico-demográficas de pacientes submetidos à cirurgia de revascularização do miocárdio e sua relação com a mortalidade. Rev Bras Cir Cardiovasc. 2012;27(1):52-60.

23. Vendites S, Almada-Filho CM, Minossi JG. Aspectos gerais da avaliação pré-operatória do paciente idoso cirúrgico. $A B C D$ Arq Bras Cir Dig. 2010;23(3):173-82.

24. Ho K, Bertenshaw C, Same S, Schneider M, Williams K, Godsell $T$, et al. Differential associations between body mass index and outcomes after elective adult cardiac surgery: a linked data cohort study. Anaesth Intensive Care. 2013;41(5):573-83.

25. De Schutter A, Lavie CJ, Patel DA, Milani RV. Obesity paradox and the heart: which indicator of obesity best describes this complex relationship? Curr Opin Clin Nutr Metab Care. 2013;16(5):517-24.
Correspondence addressed to: Simone Maria Muniz da Silva Bezerra Rua Arnóbio Marques, 310 - Santo Amaro CEP 50100-130 - Recife, PE, Brazil 